Article

\title{
The Traps of International Scripts: Making a Case for a Critical Anthropology of Gender and Sexuality in Development
}

\author{
Rahil Roodsaz ${ }^{1}$ and An Van Raemdonck ${ }^{2, *}$ \\ ${ }^{1}$ Gender and Diversity Studies, Radboud University Nijmegen, 6525 GD Nijmegen, The Netherlands; \\ E-Mail: rahil.roodsaz@gmail.com \\ 2 Social and Cultural Anthropology, Vrije Universiteit Amsterdam, 1081 HV Amsterdam, The Netherlands; \\ E-Mail: a.van.raemdonck@vu.nl \\ * Corresponding author
}

Submitted: 31 March 2018 | Accepted: 6 August 2018 | Published: 22 November 2018

\begin{abstract}
In this article, ${ }^{1}$ we look at colonialities of gender and sexuality as concepts employed in international aid and development. These international arenas reveal not only strong reiterations of modernist linear thinking and colonial continuities but also provide insights into the complexities of the implementation and vernacularisation of gender and sexuality in practices of development. Using a critical anthropological perspective, we discuss case studies based on our own research in Egypt and Bangladesh to illustrate the importance of unpacking exclusionary mechanisms of gender and sexuality scripts in the promotion of women's rights and sexual and reproductive health and rights in postcolonial development contexts. We provide a conceptual analysis of decolonial feminist attempts at moving beyond the mere critique of development to enable a more inclusive conversation in the field of development. To work towards this goal, we argue, a critical anthropological approach proves promising in allowing a politically-sensitive, ethical, and critical engagement with the Other.
\end{abstract}

\section{Keywords}

colonial; critical anthropology; development; gender; international aid; sexuality

\section{Issue}

This article is part of the issue "Gender Equality and Beyond: At the Crossroads of Neoliberalism, Anti-Gender Movements, 'European' Values, and Normative Reiterations in the Nordic Model”, edited by Lena Martinsson (University of Gothenburg, Sweden), Diana Mulinari (Lund University, Sweden) and Katarina Giritli Nygren (Mid Sweden University, Sweden).

(C) 2018 by the authors; licensee Cogitatio (Lisbon, Portugal). This article is licensed under a Creative Commons Attribution 4.0 International License (CC BY).

\section{Introduction}

Political scientist Nancy Fraser questions the rise of second-wave feminism's conjunction with the rise of neoliberalism (Fraser, 2009). Her analysis is of immediate relevance to the critical conversations surrounding the concepts of gender and sexual equality today as certain feminist ideals are still selectively employed in the shape of gender and sexual rights mainstreaming programs in international and national machineries. Fraser calls this the 'selective incorporation and partial recuperation' of some strands of feminist critique (2009, p. 99).
Similarly, Eisenstein demonstrates how US mainstream feminism has 'helped global capitalism to increase its inroads into the Global South' (2009, p. 133). As a consequence of these processes, 'gender' has become elusive and a heavily 'disputed concept in the arena of politics' (Scott, 2013). It is a discursive construct that has been ascribed many meanings. Or, as Fraser postulates, the feminist social movement has resulted in an offspring of general discursive constructs that are 'empty signifier(s) of the good' (2009, p. 114).

In this article we depart from this broader analysis of the current state of notions of gender and sexuality in ne-

\footnotetext{
${ }^{1}$ Both authors have contributed equally to this article.
} 
oliberal regimes and its extensions in development policymaking, focusing on the Global South. We aim to join a conversation of scholarship situated on the interface of postcolonial critique, critical development studies, and feminist theories with respect to gender and sexuality. Our contribution lies in advancing a critical anthropological approach to gender and sexuality in development programs, based on our ethnographic observations in Egypt and Bangladesh. We will point at approaches that are not taken and courses that are not followed due to what we call the 'scriptedness' of international interventions concerning issues of gender and sexuality.

This article focuses specifically on the uses and meanings of gender and sexuality within development programs. It examines the visible and invisible work that these concepts do in the context of postcolonial states. As early as the 1994 International Conference on Population and Development (ICPD) conference in Cairo and the 1995 Beijing Summit were held, scholars have critically examined the successes of transnational feminism (e.g., Grewal \& Kaplan, 1994; Ong, 1996, 2011; Spivak, 1995). Another wave of critique started in the early 2000s, focusing on processes of fast-growing NGO-isation and its negative effects on grassroots social movements, particularly concerning women's rights (e.g., Grewal, 2005; Jad, 2005). In the same vein, several scholars in critical/radical development studies (Baaz, 2005; Escobar, 2012; Ferguson, 1994; Kothari, 2005; K. Wilson, 2012) have argued that the political project of development is still shaped by some of the key colonial paradigms: Western sexual and gender norms are portrayed as universal, the West is seen as more developed and burdened with the task to help others and development is understood as a linear process towards desirable social change.

Simultaneously, scholars writing on the interface of development and feminist concerns have attempted to expand on these initial critiques of NGO-isation by considering the messiness and complexity of effects of NGO activism in the field of women's rights (e.g., Bernal \& Grewal, 2014; de Jong, 2009; Lashaw, Vannier, \& Sampson, 2017; Van Raemdonck, 2013). Some approach gender and development through the lens of body politics (Harcourt, 2009) and argue for thinking gender and sexuality issues in terms of human rights in a bid to advance sexual rights within an overall development goal of well-being (Cornwall, Corrêa, \& Jolly, 2008). Indeed, the initial agreements of the Cairo and Beijing conferences continue to form important international leverage for activists globally who attempt to advance women's rights and Sexual and Reproductive Health and Rights $(\mathrm{SRHR})^{2}$. The Nordic countries have been particularly active in integrating conceptions of gender and sexual equality and SRHR in their development policies (e.g., Cornwall et al., 2008, p. 1). Sweden, Norway, Denmark, and the Netherlands have started to promote the human rights of LGBTI(Q) in their core development strate- gies' (Klapeer, 2017, p. 42). Political scientist and gender studies scholar Christine M. Klapeer, among others, has warned us, however, for the 'implications' of such an LGBTIQ inclusive European political agenda. She demonstrates how these development strategies equally involve homo(trans)nationalist norms and a strengthening of the age-old belief of European sexual exceptionalism.

In this article, we aim to look at international development discourses on gender and sexuality related subjects, but focus on how such interventions play out in the Global South. We are interested in how gender and sexuality understandings operate within development projects and how they interact with local epistemologies. We agree with the necessity of a radical scrutiny of the colonial mindset and want to make a case for a critical anthropology of gender and sexuality that assesses how development projects aim to (re)shape subjectivities to fit certain expectations but often fail spectacularly. For this reason, we use the term 'scripts' to refer to the explicit goals of projects. The standardised discourse formulated in the transnational sphere can be understood as scripts that operate as blueprints for action: e.g., for gender mainstreaming, sexual education programs, Violence Against Women (VAW) initiatives, or for campaigns against practices such as FGC (Female Genital Cutting). The steps to follow and the content to be covered during activities and awareness-raising sessions are often broken down in clear-cut and easy steps, such as for example the setting up of women's crisis centres in Russia as part of the international campaign against VAW (Hemment, 2014).

An anthropological approach enables us to study scripts and what lies beyond. This means that we are more interested in examining the implicit underlying goals and detecting silences, missing elements, and paths-not-taken of projects during implementation. Through empirical case studies of campaigns against FGC in Egypt and sexual education in Bangladesh, this article engages with certain impediments brought by development scripts related to gender and sexuality issues. We illustrate how these scripts involve exclusionary mechanisms that lock out beneficiaries' participation as full subjects possessing valuable knowledge. Scripts tend to not take beneficiaries' own awareness and already existing creativity and coping strategies as starting points of the conversation but rather aim to correct those. They are pragmatically goal-oriented toward behavioural change and therefore leave little room for real conversation and dialogue between equal partners.

In the next two sections, we rely on our cases of antiFGC campaigns in Egypt and sex education promotion in Bangladesh to demonstrate the disregard of beneficiaries' own knowledge and the dominance of a secular bias. Subsequently, we aspire to move beyond deconstructionist critique and find inspiration in decolonial feminist theorising to conceive new ways forward. Our under-

\footnotetext{
${ }^{2}$ As specified in the official conference report, SRHR refers to a state of complete physical, mental, and social well-being, the ability to have a satisfying and safe sex life and the capability to reproduce and the freedom to decide if, when, and how often to do so (United Nations, 1995, p. 40).
} 
standing of critical anthropology endorses an ethical relationship with the Other through extensive investment in contextual embeddedness and openness towards categories emerging on the ground, while simultaneously resisting and questioning dominant analytical concepts and frameworks in the field of development.

Rather than a rejection of deconstructionist critique, we intend to further develop this critical approach towards new frameworks which would allow a persistent critique of development and the construction of more inclusive concepts simultaneously. This move beyond deconstruction, as we will discuss, includes a decolonial feminist call for hyper-reflexivity and replacing a sense of 'being responsible for' to 'being responsible to' (Kapoor, 2008; Spivak, 1988, 2004), feminist objectivity and situated knowledge (Haraway, 1988), and ontological justice (E. Wilson, 2017). Our understanding of 'a move beyond' is therefore not 'a move away', but an expansion and further development of deconstructionist critique. This further development is needed to both recognise the importance of development work and to envision its continuation, albeit in different ways. As aptly put by Spivak, the task is to "engage in a persistent critique of what one cannot not want" (1993, p. 284). Finally, we argue that a critical anthropology of gender and sexuality will allow analyses toward a more inclusive conversation in aid and development.

\section{FGC and Gender: Disregarding Beneficiaries' Own Knowledge of Their Bodies and Sexuality}

This section is based on ethnographic research of awareness-raising campaigns against FGC in Egypt, ${ }^{3}$ conducted between September 2012 and September 2014 in Cairo and Luxor governorates. ${ }^{4}$ FGC is a highly gendered cultural practice. It has historically been strongly tied to constructions of womanhood and femininity, particularly to the moral realm of appropriate female sexuality and other gendered social behaviours (Boddy, 1989; Fabos, 2001; Malmström, 2009). It is popularly understood by practicing communities that FGC curbs excessive female sexual desire and helps women fulfil proper gender roles. In Egypt, the century-old univocal understanding of FGC as a rite of passage for all girls has, over the last decades, been replaced by a more ambiguous understanding. This shift in meaning indicates that cam- paigning discourse has successfully been incorporated in particular medical and religious arguments.

Despite the deeply gendered nature of FGC practices, international campaigning initiatives reveal interesting paradoxes. In the international sphere, FGC is formulated as a violation of women's and children's rights, and as a form of violence against women. These articulations allow for not directly addressing the gender and sexuality norms in which FGC is locally embedded. The observed paradox is therefore that underlying male-centred hegemonic gender norms are reaffirmed during the implementation and vernacularisation of campaigns. This also means that women's present and existing knowledge of their bodies, sexuality, and gendered social norms are not taken as a departure point for a conversation about FGC but are rather set aside.

This case study looked into campaigning practices of local NGO's and consisted of participant observation of awareness-raising sessions, interviews with trainers and NGO workers, and informal conversations with beneficiaries. Contemporary campaigning in Egypt departs from international scripts while local development actors vernacularize them. Local trainers of awareness-raising sessions simultaneously adopt and subvert the international script to fit the context and to engage with the life worlds of attending women beneficiaries. The first striking observation is that during these sessions, trainers had successfully translated the international fight against FGC into a fight for marriage. Trainers argued that the consequences of FGC are harmful to women and located this harm within the context of the marital bond, the natural context of sexual relations. The harm that women may suffer, such as a lack of sexual enjoyment, becomes then part of a larger whole, the social institution of marriage. They presented the reasoning that if women cannot enjoy sex, the marital bond inevitably will suffer. In this manner, local trainers engaged with women's concern of maintaining a stable and positive marital bond in order to persuade them to abandon FGC practices, successfully drawing on contemporary understandings of marital crisis and concerns with high rates of divorce.

A second major argument presented in awarenessraising sessions is the understanding that FGC does not affect sexual desire but rather sexual enjoyment. Relying on medical knowledge, trainers stress that the organs responsible for sexual desire are not affected by FGC.

\footnotetext{
${ }^{3}$ These initiatives depart from the international policies that have been developed since the United Nations Decade of Women (1975-1985) and the subsequent international agreements. The World Conference on Human Rights in Vienna of 1993 established women's rights as an inseparable part of human rights. In December 1993, the Convention on the Elimination of Violence Against Women in New York was signed in New York, declaring FGC as a form of violence against women. The movement for the recognition of Sexual and Reproductive Rights (ICPD, Cairo 1993), the recognition of women's rights as human rights and activism against violence against women, are celebrated by activists as the most important achievements of transnational feminism.

The terminology used to describe FGC is often contested and can be described by various terms in Arabic or in English. Some terms emphasise the harm done by the practice (FGM) while others refer more to the cultural and traditional rite de passage element of which it was initially part (khitan), while other terms also carry religious references such as tahara, literally purification.

In Egypt, performing FGC has also been tightly connected to understandings of womanhood that are constructed around notions of bearing pain and bodily suffering (Malmström, 2009). After twenty years of state and NGO interventions, conventional reasoning for performing FGC has developed. Today, a popular discourse is that FGC is not always a requirement. It is considered needed when female genitalia are deemed to be in need of adjustment by medical professionals (Van Raemdonck, 2016).

${ }^{4}$ The discussion in this section is based on the PhD research project funded by the Research Foundation-Flanders (FWO) that investigated contemporary discourses and perceptions of FGC across the secular-religious divide (Van Raemdonck, 2016).
} 
The brain is still able to produce sexual desire, but the genitals are harmed in their ability to fulfil it. The message that trainers deliver is then that FGC does not control women's sexual behaviour and therefore should be dropped easily. Instead, women are told that proper female, modest behaviour can only be instilled through values, education, and upbringing. Here, trainers successfully transformed the external bodily practice that was meant to ensure proper sexual and gendered behaviour into an internal disciplinary practice of sexual morality.

These ethnographic findings reveal the consequences of international scripts. The script presents the goal and the arguments for abandoning FGC and is pragmatically goal-oriented toward behavioural change. Trainers follow the goals of the script while subverting it in their translations of arguments. In the vernacularised campaigns of this study, the departure point remains hegemonic gender and sexuality norms that are dominated by male concerns. Women appear as victims of the practice (as not being able to fully enjoy sex) while at the same time being held responsible for keeping their marriages healthy and their families united (the threat of divorce due to unsatisfying sexual relations for the husband). We could state that the international script has indeed been translated into local ones that also found their ways into social and cultural discourse and play out in concrete everyday life.

The nature of both of these discursive travels is characterised by a one-directional transmission of knowledge from campaigners endowed with authority to beneficiaries/receivers. This approach is missing an open and inclusive dialogue that recognises women's own knowledge, coping strategies, and lived realities and departs from there. The dominance of scripts leaves little space for a real, creative engagement with these topics, which means that the potential of an active engagement with women's perspectives and understandings of gendered norms remains unexplored. The potential conversation that departs from these women's lived accounts rather than from hegemonic social discourse remains unexploited, leaving important questions therefore excluded and unexplored. A discussion that departs from women's own lived sexuality could, for example, include the diverse sexual experiences of cut women, their existing coping strategies, and approaches to enhance marital understanding and sexual enjoyment. It would reveal that not all cut women feel a victim of the practice but have managed to move beyond it and do not want to be perceived as victims.

We can conclude that what we called the scriptedness of international interventions reveals important shortcomings. It fails to address women beneficiaries as fully human subjects who already possess valuable knowledge of their own bodies and sexuality. Having un- dergone FGC seems to disqualify them from such recognition. It fails to address them as subjects who are able to reflect on their own gendered and sexual behaviour and to identify the underlying gendered rationales of FGC. There is a disregard for the active agentic role of women in living their sexuality and gendered relationships. Campaigning would benefit from approaching these women as full subjects who can actively and consciously discuss or make decisions about their sexuality rather than as passive recipients of new knowledge. In many ways, these are missed opportunities for inclusive dialogue and exchange, a goal shared by feminist pedagogies based on radical egalitarianism (Mukhopadhyay \& Wong, 2007) as well as global justice actors more generally.

\section{Sexular Education: The Dominance of Secularism in SRHR Development in Bangladesh}

In this section, we will continue using a critical anthropological approach to reflect on a three-year research project called 'Breaking the Shame: Towards Improving Adolescent SRHR Education in Bangladesh' (2015-2018)..$^{5}$ Our goal is to unpack how 'sexuality' is put into practice in the field of adolescent SRHR education in Bangladesh to argue that these practices are inherently linked to a secular exclusionary mechanism. Secularism and secularity are rarely discussed in the context of sexuality and development, as 'SRHR' is rendered a universal, natural, ahistorical, trans-spatial and thus an unquestionable framework and goal. This silence, however, ignores historical specificity and normativity of 'SRHR' as a script, and the possibility of alternative epistemologies and ontologies. Furthermore, it reinforces the coloniality of sexuality through a universalisation of the secular and the particularisation of the non-secular.

Halfway through the Breaking the Shame project, as a team of researchers, we organised a workshop in Dhaka for a diverse group of Bangladeshi youth. At the end of part of the workshop, a well-experienced trainer from our team provided answers to some of the young participants' burning questions raised during the day. Discussing 'sexual diversity', the trainer wrote the acronym LGBTQI on a whiteboard and started explaining what each letter referred to. After the letter $G$, a young man who had been one of the more silent participants raised his hand, stood up, and asked: 'But this is not allowed by Islam. It's considered haram.' A girl sitting next to him immediately stood up and said in a loud and clear voice: 'That doesn't matter. It's a personal choice. Individuals have the right to choose the way they want to live their life.' The trainer took a few seconds, mentioned that in his training he was only interested in 'fact-based information' and went on with the letter B. This example shows how religion becomes opposed to individual rights and

\footnotetext{
${ }^{5}$ This project is funded by the Dutch NWO WOTRO Science for Global Development made possible by and based on the policy of the Dutch Ministry of Foreign Affairs. Four organisations collaborate on the research project, namely Radboud University Nijmegen from the Netherlands, James P. Grant School of Public Health of the BRAC University from Bangladesh, and United for Body Rights (UBR) and Adolescent Development Program (ADP) of BRAC as two leading NGOs working on SRHR in Bangladesh. The main goal of the project is to assess needs and gaps in existing SRHR education according to urban and rural adolescents as well as teachers and other important stakeholders and to develop, implement, and test improved SRHR education tools.
} 
so-called factual or scientific information. The silence of the trainer as a figure of authority implies his agreement with the girl and/or his reluctance to engage with 'the religion question'. The continuation of the training without discussing the boy's concern, furthermore, suggests a dismissal of religion as a legitimate source of knowledge in an SRHR training setting.

The importance of 'fact-based' information is emphasised by various trainers and NGO representatives in Bangladesh (Roodsaz, 2018, p. 117), which corresponds with the guideline of the Dutch organisation Rutgers ${ }^{6}$ as an important provider of sex education curricula to Bangladesh and beyond. While 'religious and traditional beliefs' are seen as either entailing 'myths and misconceptions' or too complicated and sensitive, 'fact-based' sex education is assumed to be scientifically oriented and indisputable. Sexuality education is scripted as both authoritative and free of ideology, ready to be transferred to those who lack this knowledge and are living in misconceptions. However, due to their implications in historically specific socio-cultural and political systems, sexuality education programmes are inevitably normative (Lamb, 2010; Lesko, 2010; Rasmussen, 2010, 2012) and promote particular modes of subjectivity and agency (Roodsaz, 2018). Nevertheless, religion is either not mentioned at all or merely referred to as a potential obstacle or a dangerous territory. In one of our closed meetings, a colleague expressed his worries about providing youth with a link to 'such sensitive information that is incompatible with our religious beliefs', by which he meant homosexuality. Considering, on the one hand, the issue of sensitivity, and, on the other hand, the provocative goal of the project to 'break the shame', we decided to use Dutch-based websites in order to avoid potential local backlash, without actually engaging with 'the religion question'.

This lack of engagement with religion and religiosity seems to be a common practice among different organisations working on SRHR in Bangladesh. The latter became particularly clear during the 'Gender and Sexual and Reproductive Health Conference 2018 for Young Adults' in Dhaka. In one of the Q\&A slots, a young man wanted to know how the panel consisting of Bangladeshi academic researchers approached religion in their research projects on SRHR. The replies revealed an uneasy relationship with the topic of religion: 'That wasn't part of our project. We didn't ask about people's religious beliefs.' 'Of course, religion is an important topic in our country, but our approach is based on universal human rights.' In one of the opening speeches, a representative of the Dutch embassy, as one of the main promoters and facilitator of SRHR programs in Bangladesh, emphasised the human rights approach to sexuality as part of the Dutch policy: 'In the Netherlands, we believe sex education is a human right.' As a script, SRHR education privatises religion and assumes a secular space in which human rights are promoted. This exclusion of religion from
SRHR discussions and its implicit dismissal as incompatible with universal human rights conveys a secular bias in the field of SRHR development in Bangladesh.

This secular bias is problematic for various reasons. First, it implies a self-evident link between secularism and emancipation, an assumption, for instance, problematised by Joan Scott in her influential work on 'sexularism' (Scott, 2009). Correspondingly, Nancy Lesko (2010) has argued how in presumably oppositional progressive (such as comprehensive sex education) and religion-based (such as abstinence-only sex education) programmes, in fact, the same ideals of feeling secure, free, and happy, as well as clarity, effectiveness, and stability are promoted. While Scott troubles the necessarily emancipatory quality ascribed to secularism, Lesko problematises the binary oppositions attributed to religious and secular sex education models in terms of values and ideals. Secondly, through references to 'myths and misconceptions,' the secular bias disregards religious subjectivity and agency as false consciousness. This excludes non-secular modes of agency and subjectivity beyond autonomy and individuality that are shaped by frameworks of tradition, religion, and community (Avishai, 2008; Bracke, 2008; Mahmood, 2001). Thirdly, the secular bias avoids the difficult question of how to deal with competing worldviews and ontologies. Discussing the reluctance to use the concept of religion in sex education development discussions in Bangladesh, a colleague stated: 'No researcher or practitioner dares to use the word religion. The moment you do that, you will be positioned in the conservative camp.' The field of development and religion are apparently conceived of as mutually exclusive. The so-called 'neutral' language of sex education in this field, implicitly and sometimes strategically, serves to distract those involved from engaging in a complicated, yet necessary dialogue with those positioned outside the 'secular camp'.

However, such critical accounts of the secular bias should not lead to romanticising religion by locating it outside power and ideology and presenting it as authentic and homogenous (Haraway, 1988; Spivak, 1988). The religious standpoint, rather than being unitary, can be expected to be multiple, encompassing conservative as well as progressive views. Moreover, such views might be implicated in power relations along the lines of gender, class, race, and ethnicity. As such, they are not immune to critique, 'they are not innocent positions' (Haraway, 1988 , p. 584). Furthermore, to represent those religious concerns as voiced in the field, which we have been doing in this section, is itself not a neutral act: given our specific academic institutional positionality and our background in feminist, decolonial, queer, and post-secular studies we get to 'edit' those stories (by choice, by default) while constructing an argument. As authors and researchers, we are as much complicit in the constructions of knowledge about sexuality in Bangladesh as any other actor involved, albeit the level of complicity might differ

\footnotetext{
${ }^{6}$ https://www.rutgers.nl
} 
among the actors. Our claim, rather than providing an immediate, adequate, and objective account of the field of SRHR development in Bangladesh by pointing at a secular bias, is to consider a shared conversation in which underlying power relations are recognised and religion and religious concerns can be taken seriously.

\section{Unpacking Scripted Gender and Sexuality Discourses}

In the previous two sections, we employed a critical anthropological perspective to illustrate the scriptedness of sexuality and gender discourses as we encountered them in the fields of FGC-prevention and SRHR promotion in Egypt and Bangladesh, respectively. While the international anti-FGC and sex education programmes imply neutrality and universality of rights and health, we showed how in practice such efforts convey exclusionary mechanisms by neglecting and silencing competing perspectives and accounts. In the case of FGC-prevention in Egypt, women's own knowledge of their bodies and sexuality is disregarded due to an international and vernacularised scripted discourse that focuses on transmitting 'proper knowledge'. In the context of sex education in Bangladesh, we argued, a secular bias informs the dismissal of non-secular ontologies as opposed to a fact-based rights-oriented framework. We argued that both a politics of knowledge and a politics of being work together in these interventions, revealing their colonial heritage (Savransky, 2017). Together, our analyses point to the importance of a critical engagement with gender and sexuality programs as scripted interventions in development to enable a more inclusive conversation, a goal that we share with many actors involved in development. In the next section, we will engage with feminist decolonial accounts of (the possibility of) such an endeavour.

\section{Feminist Decolonial Accounts of a Move beyond Deconstruction}

As a way to move beyond colonial as well as problematic native representations of the 'Third World' as merely 'speaking for' or 'speaking about', Ilan Kapoor (2004) engages with the work of Gayatri Chakravorty Spivak on the 'subaltern'. Kapoor particularly draws inspiration from Spivak's call for hyper-reflexivity among those complicit in the development, either as (academic) researchers or practitioners. He reminds us of how even attempts at 'valorising local knowledge' to 'empower' the subaltern to determine much of the development agenda, may risk reinforcing a mainstream liberal approach that assumes autonomy and speakability. Even good intentions might thus, yet again, result in silencing the subaltern (Spivak, 1988). This leads both authors to conclude that we need to move beyond yet remain in deconstruction. This ongoing critical approach, as Kapoor outlines, should encompass several components and qualities: tempering and contextualising claims; opening up possibilities for 'unlearning' of prejudices and habits by tracing them through history; allowing for a reconsideration of 'the problem' that we desperately want to solve as well as a reconsideration of dominant concepts such as 'democracy' and 'participation'; preparing ourselves for an 'unexpected response' such as the possibility of the irretrievable heterogeneity or non-speakingness of the subaltern and a reversal of information and knowledge production. As the basis of this hyper-reflexivity, Kapoor and Spivak suggest establishing an ethical relationship with the subaltern, which would enable us to 'respond to the appeal of the Other'. Through an intimate and a dialogical engagement with the Other, we might be able to replace a sense of 'being responsible for' to a sense of 'being responsible to'.

Although not focused on the field of development, Donna Haraway (1988)'s work on 'situated knowledge' provides important insights for a process of decolonisation beyond and within deconstruction. Addressing feminist scholarship, Haraway engages with 'feminist objectivity' as a situated account of all knowledge claims as historically contingent and a 'no-nonsense commitment' (1988, p. 579) to understand the 'real' world. Rejecting the universal 'conquering gaze', Haraway suggests constructing a usable, yet not innocent, feminist objectivity. By acknowledging and exploring the particularity and embodiment of one's necessarily partial perspective, she postulates, objective vision becomes possible. While she underscores the importance of learning how to see from another point of view, she also warns against romanticising the vision of the less powerful. The position of the less powerful, she explains, is 'not exempt from critical re-examination, decoding, deconstruction, and interpretation' (Haraway, 1988, p. 584). At the same time, Haraway (1988) continues, we need to come to terms with the agency of the 'objects' studied by resisting the politics of closure and finality. This approach requires a paradoxical mode of 'passionate detachment' as a simultaneous investment in seeking new unpredictable perspectives and the contestation of those perspectives. The possibility of a web of connections, solidarity, and conversation only becomes available, Haraway claims, when a joining of partial views, 'views from somewhere' (1988, p. 590), can take place. The goal is not to collect multiple voices, but to provide grounds for a powersensitive conversation.

As a contribution to this discussion on the (im)possibility of a conversation in development, Erin Wilson (2017) argues for including 'ontological injustice' in our critical analyses, which engages with 'views of alternative worlds' (2017, p. 1077). Ontological injustice, Wilson explains, regards the possibility of other worlds rather than alternative views of the same world. This form of injustice, she argues, has received limited attention in the field of development (compared to material and epistemological injustices), yet is necessary to engage with in order to allow for more inclusive conversations and interactions across ontologies. Moreover, according to Wilson interrogating ontological injustices problema- 
tises the mere focus on 'translation', as translation 'can only be done through the imposition of categories and frames from one ontology to another' (2017, p. 1088). Instead, using insights from 'the ontological turn' in cultural anthropology, Wilson suggests to critically investigate dominant ontologies in development settings. The examples we have provided in sections two and three illustrate such an investigation, which we call 'critical anthropology'. Following these critical examinations, Wilson proposes cross-ontological communication and dialogue, which require new and shared categories to emerge in practice on the ground. As part of this anthropological commitment to contextual embeddedness, the necessity of multilingualism among theorists and practitioners could be considered, a proposition also made by Spivak (Spivak, 2004).

Combined, these suggestions for moving beyond deconstruction imply a fundamentally ethical engagement. This engagement is understood as an intensive and intimate endeavour that is simultaneously politically sensitive, as it is concerned with positionality and the situatedness of knowledge, regardless of whether this knowledge is produced by 'experts' or 'local' actors. While it aims for solidarity and an inclusive conversation, this ethical engagement promotes a critical commitment through resisting homogeneity, closure, and universalism, which requires an open attitude and an active search for alternative ontologies, not because we expect them to be better, but because they are needed to organise a more inclusive conversation.

\section{Conclusions}

In this article, we engaged with colonial continuities of gender and sexuality in international development interventions. International development and European national development programs aim to engage more and more with gender and sexual equality values. Especially Nordic countries have been prominent actors in incorporating LGBTIQ-inclusive measures in their development policies. We started with pointing at how such interventions, despite their best intentions, often reinforce civilisational West-versus-non-West dichotomies, while serving neoliberal agendas through depoliticisation and universalisation of the categories of gender and sexuality. In the two empirical middle sections, we provided an analysis of anti-FGC campaigns in Egypt and sex education programs in Bangladesh as two examples of developmentoriented efforts to improve women's and young people's rights. We employed a critical anthropological perspective to point out that despite being presented as universal and neutral, such interventions are highly scripted in terms of both methodology and content. The interventions' methods are based on the unilateral transmission of knowledge or 'awareness', rather than a two-way interactionist open and inclusive dialogue. The programs' content disregards existing and competing knowledge and ontologies. These scripted features consequently contain exclusionary mechanisms such as silencing beneficiaries' own accounts of embodied knowledge and imposing a secular discourse.

Feminist decolonial accounts on the need to move beyond still remain in deconstruction, we outlined, provide valuable insights and tools to facilitate a more inclusive conversation through an ethical engagement with the Other. This will remain an ongoing process that should resist the desire for closure and finality, for which, we argued, critical anthropology forms a promising framework. However, this search for ontological justice could be challenging as not all actors in development projects might agree upon its terms of non-universality and nonclosure. As discussed in the section about a secular bias in the SRHR field in Bangladesh, religious concerns can be as much an expression of genuine spirituality as they may be of worldly power, including dogmatism, extremism, and exploitation. This sheds light on the importance of a persistent critical approach while pursuing ontological justice. Engaging with this challenge remains an ongoing discussion among scholars within decolonial studies, as, for instance, can be found in the work of Collins (2017) on transversal politics, flexible solidarity, and coalition building.

Due to its commitment to understanding alternative ontologies, critical anthropology requires extensive investment in contextual embeddedness and openness towards categories emerging on the ground. Moreover, because of the emphasis on the unique relationship between the researcher and the interlocutor, critical anthropology allows for a situated and embodied understanding of this relationship. Such a critical anthropological account has the potential to endorse an ethical relationship with the Other by being responsive to its appeal while avoiding its romanticised and paternalistic representations.

\section{Acknowledgments}

First and foremost, we are indebted to all those involved in our case studies either as research subjects or as practitioners and researchers. The case study on anti-FGC campaigning in Egypt was part of a PhD research project funded by the Research Foundation-Flanders (FWO), conducted at Ghent University, Belgium, and the case study on sex education in Bangladesh is part of on an SRHR international research project (W08560003) which is financed by The Netherlands Organisation for Scientific Research (NWO). Both authors have contributed equally to this article.

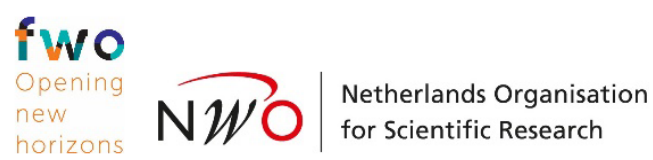

\section{Conflict of Interests}

The authors declare no conflict of interests. 


\section{References}

Avishai, O. (2008). 'Doing religion' in a secular world. Gender \& Society, 22(4), 409-433. doi:10.1177/ 0891243208321019

Baaz, M. E. (2005). The paternalism of partnership: A postcolonial reading of identity in development aid. London: Zed.

Bernal, V., \& Grewal, I. (Eds.). (2014). Theorizing NGOs, states, feminisms, and neoliberalism. Durham and London: Duke University Press.

Boddy, J. P. (1989). Wombs and alien spirits: Women, men, and the Zār Cult in Northern Sudan. Madison, WI: University of Wisconsin Press.

Bracke, S. (2008). Conjugating the modern/religious, conceptualizing female religious agency. Theory, Culture \& Society, 25(6), 51-67. doi:10.1177/ 0263276408095544

Collins, P. H. (2017). On violence, intersectionality and transversal politics. Ethic and Racial Studies, 40(9), 1460-1473.

Cornwall, A., Corrêa, S., \& Jolly, S. (Eds.). (2008). Development with a body: Sexuality, human rights and development. London and New York: Zed Books.

de Jong, S. (2009). Constructive complicity enacted? The reflections of women NGO and IGO workers on their practices. Journal of Intercultural Studies, 30(4), 387-402. doi:10.1080/07256860903214131

Eisenstein, H. (2009). Feminism seduced: How global elites use women's labor and ideas to exploit the world. Boulder, CO: Paradigm Publishers.

Escobar, A. (2012). Encountering development: The making and unmaking of the Third World. Princeton: Princeton University Press.

Fabos, A. H. (2001). Embodying transition: FGC, displacement, and gender-making for Sudanese in Cairo. Feminist Review, 69(1), 90-110.

Ferguson, J. (1994). The anti-politics machine: "Development," depoliticization, and bureaucratic power in Lesotho. Minneapolis, MN: University of Minnesota Press.

Fraser, N. (2009). Feminism, capitalism and the cunning of history. New Left Review, 56, 97-117.

Grewal, I. (2005). Transnational America. Durham and London: Duke University Press.

Grewal, I., \& Kaplan, C. (1994). Scattered hegemonies: Postmodernity and transnational feminist practice. Minneapolis, MN: University of Minnesota Press.

Haraway, D. (1988). Situated knowledges: The science question in feminism and the privilege of partial perspective. Feminist Studies, 14(3), 575-599.

Harcourt, W. (2009). Body politics in development, critical debates in gender and development. London: Zed Books.

Hemment, J. (2014). Global civil society and the local costs of belonging. Defining violence against women in Russia. In V. B. I. Grewal (Ed.), Theorizing NGOs. States, feminisms, and neoliberalism (pp. 119-142).
Durham and London: Duke University Press.

Jad, I. (2005). The NGO-isation of Arab women's movements. IDS Bulletin, 35(4), 34-42.

Kapoor, I. (2004). Hyper-self-reflexive development? Spivak on representing the Third World 'Other'. Third World Quarterly, 25(4), 627-647. doi:10.1080/ 01436590410001678898

Kapoor, I. (2008). The postcolonial politics of development. London and New York: Routledge.

Klapeer, C. M. (2017). Queering development in homotransnationalist times: A postcolonial reading of LGBTIQ inclusive development agendas. Lambda Nordica, 2/3, 41-67.

Kothari, U. (2005). Authority and expertise: The professionalisation of international development and the ordering of the dissent. Antipode, 37(3), 425-446.

Lamb, S. (2010). Feminist ideals for a healthy female adolescent sexuality: A critique. Sex Roles, 62(5), 294-306. doi:10.1007/s11199-009-9698-1

Lashaw, A., Vannier, C., \& Sampson, S. (2017). Cultures of doing good: Anthropologists and NGOs. Tuscaloosa, AL: The University of Alabama Press.

Lesko, N. (2010). Feeling abstinent? Feeling comprehensive? Touching the affects of sexuality curricula. Sex Education, 10(3), 281-297. doi:10.1080/ 14681811.2010.491633

Mahmood, S. (2001). Feminist theory, embodiment, and the docile agent: Some reflections on the Egyptian Islamic revival. Cultural Anthropology, 16(2), 202-236. doi:10.1525/can.2001.16.2.202

Malmström, M. B. (2009). Just like couscous: Gender, agency and the politics of female Circumcision in Cairo (PhD dissertation). University of Gothenburg, Sweden.

Mukhopadhyay, M., \& Wong, F. (2007). Revisiting gender training: The making and remaking of gender knowledge. A global sourcebook. Amsterdam: Oxfam Publishing.

Ong, A. (1996). Strategic sisterhood or sisters in solidarity? Questions of communitarianism and citizenship in Asia. Indiana Journal of Global Legal Studies in Family Planning, 4(1), 107-135.

Ong, A. (2011). Translating gender justice in Southeast Asia: Situated ethics, NGOs, and bio-welfare. Journal of Women in the Middle East and the Islamic World, 9, 26-48.

Rasmussen, M. L. (2010). Secularism, religion, and 'progressive' sex education. Sexualities, 13(6), 699-712. doi:10.1177/1363460710384558

Rasmussen, M. L. (2012). Pleasure/desire, sexularism and sexuality education. Sex Education, 12(4), 469-481. doi:10.1080/14681811.2012.677204

Roodsaz, R. (2018). Probing the politics of comprehensive sexuality education: 'Universality' versus 'cultural sensitivity': A Dutch-Bangladeshi collaboration on adolescent sexuality education. Sex Education, 18(1), 107-121. doi:10.1080/ 14681811.2017.1403894 
Savransky, M. (2017). A decolonial imagination: Sociology, anthropology and the politics of reality. Sociology, 51(1), 11-26. doi:10.1177/0038038516656983

Scott, J. W. (2009). Sexularism: On secularism and gender equality. Ursula Hirschmann Annual Lecture at the European University Institute, Florence 23 April. Retrieved from http://cadmus.eui.eu/bitstream/ handle/1814/11553/RSCAS_DL_2009_01.pdf

Scott, J. W. (2013). The uses and abuses of gender. Tijdschrift voor Genderstudies, 16(1), 63-77.

Spivak, G. C. (1988). Can the subaltern speak? In C. Nelson \& L. Grossberg (Eds.), Marxism and interpretation of culture (pp. 271-313). Chicago, IL: University of Illinois Press.

Spivak, G. C. (1993). Outside in the teaching machine. London: Routledge.

Spivak, G. C. (1995). 'Woman' as theatre: United Nations Conference on Women, Beijing 1995. Radical Philosophy, 75, 2-4.
Spivak, G. C. (2004). Righting wrongs. The South Atlantic Quarterly, 103(2/3), 523-581.

United Nations. (1995). Report of the International Conference on Population and Development, Cairo, 5-13 September 1994. New York: United Nations.

Van Raemdonck, A. (2013). Egyptian activism against female genital cutting as catachrestic claiming. Religion and Gender, 3(2), 222. doi:10.18352/rg.9169

Van Raemdonck, A. (2016). Female genital cutting and the politics of Islamicate practices in Egypt: Debating development and the religious/secular divide ( $\mathrm{PhD}$ dissertation). Ghent University, Belgium.

Wilson, E. (2017). 'Power differences' and 'the power of difference': The dominance of secularism as ontological injustice. Globalizations, 14(7), 1076-1093. doi:10.1080/14747731.2017.1308062

Wilson, K. (2012). Race, racism and development: Interrogating history, discourse and practice. London: Zed.

\section{About the Authors}

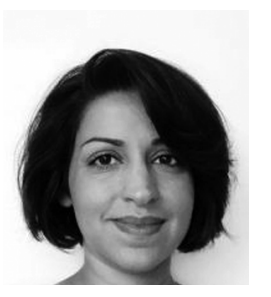

Rahil Roodsaz is a cultural Anthropologist, specialised in sexuality, subjectivity, and diversity. In 2015, she obtained her PhD on 'Sexual Self-Fashioning among the Iranian Dutch' in cultural anthropology and gender studies at the Institute for Gender Studies of the Radboud University Nijmegen. She is currently a Postdoctoral Researcher in Gender and Diversity Studies at the same university, working on adolescent sexuality education in Bangladesh.

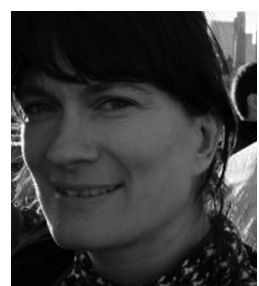

An Van Raemdonck is a Postdoc Researcher at the Department of Social and Cultural Anthropology at VU Amsterdam in the Netherlands. She received her PhD in Comparative Science of Cultures at Ghent University in 2016 as an FWO fellow (Research Foundation-Flanders). Her current project is funded by The Netherlands Organisation for Scientific Research (NWO) and examines early marriage practices and sexual and reproductive health programs among Syrian refugees in Jordan. Her research interests include critical development and postcolonial theory. 